\title{
GENDER PAY GAP: \\ EVIDENCE FROM THE CZECH PRIVATE COMPANY
}

\author{
Gabriela Polakova ${ }^{1}$
}

Received: November 7, 2019 / Revised: January 16, 2020 / Accepted: February 12, 2020

(C) Association of Economists and Managers of the Balkans, 2020

\begin{abstract}
The aim of this article is to find out if in the analyzed company there exists a pay discrimination between women and men. If so, how big it is and what impact it has on real salaries. In the analyzed company the survey was focused on the salaries' differentiation of random sample of 30 women and 30 men working on the same or similar positions, enrolled in the same pay scales and working full time. The prerequisite for the distribution of salaries in the population was a normal distribution. The construction of two-sided confidence interval for estimating salary variation in the population was based on $\chi^{2}$ distribution and give us a reply on the question at what interval the standard deviation of salaries in the population of all men and women in the company can be expected with $95 \%$ probability. For this purpose, there was used the estimate of variance of the population. Findings show a still occurring gender pay gap.
\end{abstract}

Keywords: Equal Pay, Sex Bias, Gender Discrimination, Salaries Differentiation, Estimate of Variance of the Population.

\section{JEL Classification J16}

This paper was presented at the Third International Scientific Conference on IT, Tourism, Economics, Management and Agriculture - ITEMA 2019 - October 24, Bratislava, Slovakia, www.itema-conference.com

\section{Gabriela Polakova}

gabriela.polakova@post.cz

1 VSB-Technical University of Ostrava, Faculty of Economics, Sokolska trida 33, 70200 Ostrava, Czech Republic 


\section{INTRODUCTION}

As Armstrong (2005) has stated: "discrimination arises when equals are treated unequally" (p. 131). Historically, the position of women and men on the labor market has changed and is related to the social status of women, the possibility of obtaining and then apply their education and the legitimacy of being economically self-sufficient and independent of men. First women obtained work based on their care skills. Already here we can see the beginnings of the gender segregation of labor which is still a significant cause of unequal pay. During the war, women were pragmatically allowed to enter the labor market and were recruited into the male professions because of the lack of male labor. After the war, the economic emancipation of women and their participation in the labor market was generally supported. However, family and household care still remain the domain of the woman till today. Historically, inequality between men and women has concerned segregation into different occupations as well as unequal pay. The Czech labor market has retained these specifics even after the revolution in 1989 till today. Economic theories monitor the influence of gender, age, education, the number of years of work, the influence of maternity and career breaks, the influence of market segregation, the influence of legislative activities and legal norms, the institutional influence of trade unions and so on. Maternity has a major impact on women's wages and careers. There are still lots of employers who perceive parenthood as incompatible with careers or full-time job based on statistically unsubstantiated assumptions of frequent absence of mothers at work or false unsubstantiated assumptions about the lack of leadership and management skills which are assessed as psychologically demanding and very time-consuming and therefore gender predetermined for men. According to Armstrong et all (2005), "Extended pay ranges, especially where progression is based on length of service, will favor men who are much less likely than women to have career breaks and may therefore progress further and faster" (p. 133). According to the research made by Hodges et all (2010), fathers in the labor market receive the so-called paternal bonus (i.e. higher wages) compared to mothers and childless men on the assumption that they are a stable and loyal workforce in connection with fulfilling a breadwinner role. Hultin and Szulkin (2003) confirm that where are more women managers, there is a lower level of internal gender segregation and women managers pay more attention to gender equality issues, including equal pay. According to Song et all (2019), "Gender pay equity is a desirable social value and an important strategy to fill every organizational stratum with gender-diverse talent to fulfill an organization's goals and mission.” (p. 830). Yamamoto et all (2019) investigates how educational attainment affects occupational choice for men and women in urban and rural areas. Rafferty (2019) examines the effects of discrimination based on race, ethnic background, nationality, religion, sex, age, disability and sexual orientation on skill underutilization and under-skilling in 30 European countries. He stated, "People who experienced a variety of forms of workplace discrimination were more likely to report over-skilling, defined as having skills for more demanding roles than required for their job." Kronberg (2019) found "men often receive greater merit rewards than women for the same performance." He also stated, "gender disparities are significant only when supervisors have discretion over merit increases." According to Larraz et all (2019), "As long as men earn more per hour on average than women, gender wage inequality (understood as the differences on wage between each man and each woman will remain)" (p. 18). They stated, „,vast majority of directors and senior executives working for big companies are men is at the root of the problem" (p. 19). Sato et all (2019) stated, "job segregation by gender is one major cause of the widely observed gender pay gap and that there are also gender differences in developmental job assignment for broader job experience". Bargain et all (2019) found evidence that the gender wage gap at the bottom of the wage distribution may be effectively reduced by a national minimum wage. (p. 532) According to Maume et all (2019), "As European countries have mandated quotas for women's representation on boards, and as women have increasingly 
entered the ranks of management, a persistent gender gap in managerial pay remains." Cook et all (2019) stated, "the more direct influence women have over compensation decisions, the smaller the compensation gap." (p. 1292). The Ministry of Labor and Social Affairs on the official webpage informs that the gender pay gap was $21,1 \%$. Krizkova et all (2018) found "comparing internationally, the Czech Republic ranks among the countries in which wage variability, or more precisely wage inequality, significantly increased between 2002 and 2016 (p. 9). She stated, "The Czech Republic is a country with one of the highest levels of gender pay inequality." (Krizkova et all, 2018, p. 99).

\section{METHODOLOGY}

The estimate of variance of population $\sigma^{2}$ is a sample variance which is a distortion-free and consistent estimate, i.e.

$$
\sigma^{2}=s_{x}^{\prime 2}
$$

where sample variance is calculated according to the relationship:

$$
s_{x}^{\prime 2}=\frac{\sum_{i=1}^{n}\left(x_{i}-\bar{x}\right)^{2}}{n-1}
$$

In constructing the confidence interval, we assume that the quantity

$$
\frac{(n-1) s_{x}^{\prime 2}}{\sigma^{2}}
$$

has $\chi^{2}$ distribution with $v=n-1$ degrees of freedom. The confidence interval is derived from the relationship

$$
P\left(\chi_{\frac{\alpha}{2}}^{2}<\frac{(n-1) s_{x}^{\prime 2}}{\sigma^{2}}<\chi_{\frac{1-\alpha}{2}}^{2}\right)=1-\alpha
$$

Adjusting the inequality in parentheses we get a two-sided $100(1-\alpha) \%$ confidence interval for variance in the population

$$
\frac{(n-1) s_{x}^{\prime 2}}{\chi_{\frac{1-\alpha}{2}}^{2}}<\sigma^{2}<\frac{(n-1) s_{x}^{\prime 2}}{\chi_{\frac{\alpha}{2}}^{2}}
$$

Where $\chi_{\frac{\alpha}{2}}^{2}$ and $\chi_{\frac{1-\alpha}{2}}^{2}$ are quantiles of the distribution with $v=n-1$ degrees of freedom. For more information please see (Hindls et all, 2006).

Hypothesis testing used in this paper is based on a random sample, there was verified if the average of the population $\mu$ is equal to a certain value of $\mu_{0}$. The null hypothesis is formulated $H_{0}: \mu=\mu_{0}$. Alternative hypothesis is in the following practical case formulated $H_{1}: \mu<\mu_{0}$. Assuming that the variance in the population is known, we select the following formula as the test criterion

$$
U=\frac{\bar{x}-\mu_{0}}{\sigma} \sqrt{n}
$$

If we do not know the variance of the population, we estimate it by the sample variance

$$
U=\frac{\bar{x}-\mu_{0}}{s_{x}^{\prime}} \sqrt{n}
$$




\section{SURVEY OF MEN'S AND WOMEN'S SALARIES IN THE CZECH PRIVATE INDUSTRIAL COMPANY}

The survey on differentiation of women's and men's salaries was focused on target group of technical economic employees who work in the same or in the similar position and are included in the same pay scale. According to information received from HR their salaries differ by personal bonuses, commute surcharges, long-term loyalty bonuses etc. Totally 816 employees in the technical-economic professions work in the company. 60 employees working in the same or similar position were randomly selected. 30 salaries of women were compared with 30 salaries of men. There was studied if there is any influence of parenting on salaries of women and men in this random sample. The assumption is that the distribution of salaries in the population of all technical-economic staff is normal. On the random sample there were calculated average salaries and standard deviations of both group and compared together. In the following Table 1 " $\mathrm{X}$ " represents salary " $\mathrm{f}(\mathrm{x})$ " represents distribution function of the normal distribution and " $\mathrm{F}(\mathrm{x})$ " represents the probability density function of the normal distribution both graphically shown on Figure 1.

Table 1. Salaries of women and men and calculations

of distribution functions of the normal distribution

Source: own calculations

\begin{tabular}{|c|c|c|c|c|c|c|c|}
\hline \multicolumn{4}{|c|}{ Women } & \multicolumn{4}{|c|}{ Men } \\
\hline $\mathbf{X}$ & Mother & $f(x)$ & $F(x)$ & $\mathbf{X}$ & Father & $f(x)$ & $F(x)$ \\
\hline 28121 & $\mathrm{NO}$ & 0,0564683 & 0,0000645 & 31150 & $\mathrm{NO}$ & 0,0375458 & 0,0000435 \\
\hline 28453 & $\mathrm{NO}$ & 0,0812507 & 0,0000854 & 31630 & $\mathrm{NO}$ & 0,0636644 & 0,0000663 \\
\hline 28479 & $\mathrm{NO}$ & 0,0834932 & 0,0000871 & 32080 & $\mathrm{NO}$ & 0,0993112 & 0,0000928 \\
\hline 28970 & YES & 0,1349503 & 0,0001232 & 32110 & $\mathrm{NO}$ & 0,1021247 & 0,0000947 \\
\hline 29150 & YES & 0,1583808 & 0,0001372 & 32730 & $\mathrm{NO}$ & 0,1736279 & 0,0001364 \\
\hline 29340 & YES & 0,1858474 & 0,0001519 & 32856 & $\mathrm{NO}$ & 0,1913479 & 0,0001449 \\
\hline 29340 & YES & 0,1858474 & 0,0001519 & 32890 & $\mathrm{NO}$ & 0,1963131 & 0,0001472 \\
\hline 29460 & YES & 0,2046294 & 0,0001611 & 33450 & $\mathrm{NO}$ & 0,2887123 & 0,0001816 \\
\hline 29589 & YES & 0,2260296 & 0,0001707 & 33543 & YES & 0,3058288 & 0,0001864 \\
\hline 29609 & $\mathrm{NO}$ & 0,2294572 & 0,0001721 & 33550 & $\mathrm{NO}$ & 0,3071352 & 0,0001868 \\
\hline 29780 & YES & 0,2599217 & 0,0001841 & 33680 & $\mathrm{NO}$ & 0,3318266 & 0,0001930 \\
\hline 29805 & YES & 0,2645441 & 0,0001857 & 33750 & $\mathrm{NO}$ & 0,3454401 & 0,0001960 \\
\hline 30035 & YES & 0,3089373 & 0,0001999 & 33890 & $\mathrm{NO}$ & 0,3732597 & 0,0002013 \\
\hline 30210 & YES & 0,3447455 & 0,0002090 & 33910 & YES & 0,3772924 & 0,0002020 \\
\hline 30345 & $\mathrm{NO}$ & 0,3733747 & 0,0002149 & 34230 & YES & 0,4433515 & 0,0002099 \\
\hline 30760 & $\mathrm{NO}$ & 0,4651765 & 0,0002256 & 34580 & YES & 0,5173859 & 0,0002119 \\
\hline 30990 & $\mathrm{NO}$ & 0,5172022 & 0,0002262 & 34596 & $\mathrm{NO}$ & 0,5207755 & 0,0002118 \\
\hline 31020 & $\mathrm{NO}$ & 0,5239855 & 0,0002260 & 34670 & $\mathrm{NO}$ & 0,5364288 & 0,0002112 \\
\hline 31098 & NO & 0,5415847 & 0,0002252 & 34750 & YES & 0,5532874 & 0,0002102 \\
\hline 31150 & YES & 0,5532745 & 0,0002244 & 35134 & YES & 0,6323629 & 0,0002003 \\
\hline 31240 & $\mathrm{NO}$ & 0,5733922 & 0,0002226 & 35469 & YES & 0,6971478 & 0,0001856 \\
\hline 31280 & $\mathrm{NO}$ & 0,5822756 & 0,0002216 & 35509 & YES & 0,7045320 & 0,0001836 \\
\hline 31295 & $\mathrm{NO}$ & 0,5855964 & 0,0002212 & 35958 & YES & 0,7811795 & 0,0001569 \\
\hline 31709 & $\mathrm{NO}$ & 0,6740744 & 0,0002045 & 36449 & YES & 0,8501820 & 0,0001239 \\
\hline 31790 & YES & 0,6904627 & 0,0002001 & 36587 & YES & 0,8666253 & 0,0001145 \\
\hline 31879 & $\mathrm{NO}$ & 0,7080418 & 0,0001949 & 37239 & YES & 0,9274699 & 0,0000734 \\
\hline 32020 & $\mathrm{NO}$ & 0,7348984 & 0,0001859 & 37432 & YES & 0,9405974 & 0,0000628 \\
\hline 32352 & YES & 0,7927837 & 0,0001623 & 37591 & YES & 0,9499468 & 0,0000549 \\
\hline 33467 & $\mathrm{NO}$ & 0,9263203 & 0,0000793 & 37628 & YES & 0,9519446 & 0,0000531 \\
\hline 34468 & $\mathrm{NO}$ & 0,9781536 & 0,0000296 & 38514 & YES & 0,9836209 & 0,0000217 \\
\hline
\end{tabular}


The probability density functions of the normal distribution of womens' and mens' salaries

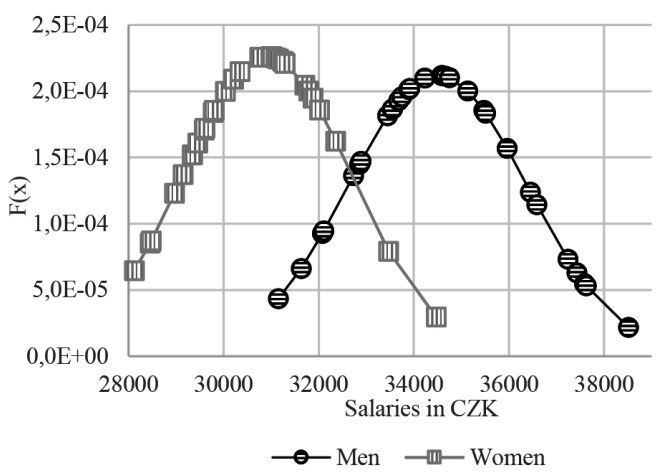

Distribution functions of the normal distribution of womens' and mens' salaries

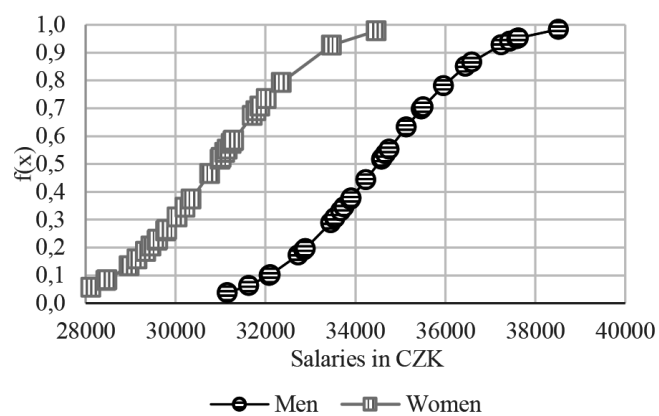

Figure 1. Distribution of women's and men's salaries in the random sample Source: own calculations

Table 2. Gender statistics calculated from the random selected population in the analysed company

Source: own calculations

\begin{tabular}{|l|c|c|c|c|c|c|}
\hline \multirow{2}{*}{ Statistics } & \multirow{2}{*}{ Women } & \multirow{2}{*}{ Men } & \multirow{2}{*}{ Ratio } & \multicolumn{2}{|c|}{ Differences } & \multirow{2}{*}{ All } \\
\cline { 5 - 7 } & & & & Rel. & Abs. & \\
\hline Average & 30573 & 34585 & $88 \%$ & $12 \%$ & 4012 & 32579 \\
\hline Median & 30553 & 34405 & $89 \%$ & $11 \%$ & 3853 & 32095 \\
\hline Max & 34468 & 38514 & $89 \%$ & $11 \%$ & 4046 & 38514 \\
\hline Min & 28121 & 31150 & $90 \%$ & $10 \%$ & 3029 & 28121 \\
\hline Standard deviation & 1451 & 1902 & $76 \%$ & $24 \%$ & 451 & 2624 \\
\hline
\end{tabular}

The median salary is the real salary of the employee in the middle of the salary distribution. The average salary is the sum of all earnings in the population under review divided by the number of women and/or men in the population. The average has the advantage that it counts all the earnings in the sample, but it is disadvantageous in that it is influenced by limit values that distort it to some extent. In the random sample the average gross salary in 2019 was 32.579 (men: 34.585 CZK; women: $30.573 \mathrm{CZK}$ ). The median gross monthly salary in the sample in 2019 was $32.095 \mathrm{CZK}$ (men: $34.405 \mathrm{CZK}$; women: $30.553 \mathrm{CZK}$ ). It is possible to say that men earn in average $4.012 \mathrm{CZK}$ a month more than women. The average monthly salary of women is $88 \%$ of the average monthly salary of men. In other words, women are remunerated on average $12 \%$ less per month than men.

Table 3. Gender comparison with focus on an influence of parenthood on salaries Source: own calculations

\begin{tabular}{|c|c|c|c|c|c|c|c|c|}
\hline \multirow{3}{*}{$\begin{array}{c}\text { Average } \\
\text { salary }\end{array}$} & \multicolumn{2}{|c|}{ Women } & \multicolumn{2}{c|}{ Difference } & \multicolumn{2}{c|}{ Men } & \multicolumn{3}{c|}{ Difference } \\
\cline { 2 - 10 } & Mother & Childless & Abs. & Rel. & Father & Childless & Abs. & Rel. \\
\cline { 2 - 10 } & 30075 & 30955 & -880 & $-3 \%$ & 35908 & 33074 & 2834 & $9 \%$ \\
\hline
\end{tabular}

The data in Table 3 show that mothers earn monthly less compared to childless women (abs. -880 CZK, rel. $-3 \%$ ). In contrast, fathers earn monthly more than childless men (abs. 2.834 CZK, rel. $9 \%$ ).

The next task is to find out at what interval the standard deviation of the salaries of technical-economic workers in the whole analyzed company could be expected with $95 \%$ probability. For this 
purpose, a two-sided confidence interval was used for estimating the salary variance of technical-economic workers in the company which is compiled according to Formula 4.

Table 3. Gender estimation of salary variance - all female and male population in the company Source: own calculations

\begin{tabular}{|c|c|c|}
\hline Women & Men & All \\
\hline$\frac{(30-1) 1451^{2}}{45,7}<\sigma^{2}<\frac{(30-1) 1451^{2}}{17,7}$ & $\frac{(30-1) 1902^{2}}{45,7}<\sigma^{2}<\frac{(30-1) 1902^{2}}{17,7}$ & $\frac{(30-1) 2624^{2}}{45,7}<\sigma^{2}<\frac{(30-1) 2624^{2}}{17,7}$ \\
\hline $1156<\sigma<1857$ & $1515<\sigma<2435$ & $2090<\sigma<3359$ \\
\hline
\end{tabular}

The standard deviation of salaries in the company can be expected with $95 \%$ confidence at the interval of $1156<\sigma<1857$ for women, at the interval of $1515<\sigma<2435$ for men and at the interval of $2090<\sigma<3359$ for both sexes.

According to published information on the website of the Czech Ministry of Labor and Social Affairs the difference between the average salary of a woman and the average salary of a man is almost CZK 7.000 per month. The total pay gap in the Czech Republic is $21.1 \%$ which has been stable in the long-term since 2002. Comparing with findings in the random sample in the analyzed company the difference looks better: abs. CZK 4.012 and rel. $13 \%$. Can the difference be attributed to chance, or is there a sign of an improvement in the gender pay gap in this company? Let's make a testing hypothesis. The null hypothesis in this case is $H_{0}: \mu=7000$. Unilateral alternative hypothesis $H_{1}: \mu=4012$. The test is performed at the significance level $\alpha=0,05$. The test criterion value is calculated using the Formula 7.

$$
U=\frac{4012-7000}{2624} \sqrt{60}=-8,8205
$$

In the one-sided test and the given level of significance $\alpha=0,05$, the critical range is given by a set of values lower than -1.645 , i.e. $W=\{U ; U \leq-1,645\}$. The null hypothesis is rejected in favor of the alternative hypothesis at the $5 \%$ significance level because the test criterion value $-8,8205<-1,645$. Thus, with a 5\% risk of error, it can be argued that the gender pay gap in the analyzed company is lower than Czech national one and the difference found between the national gender pay gap and the company gender pay gap found in the random sample cannot be attributed to chance.

\section{FUTURE RESEARCH DIRECTIONS}

Fair pay, flexible working conditions, seeking work life balance are key issues especially for women with children. Gender stereotypes are still deeply rooted in the Czech society. A next future research could be directed to answer a question: "Why Czech women (or women generally in the west type of culture) are not usually able to negotiate the same wages as men". The next efforts could be focused on finding ways to minimize wage inequalities, wage discrimination and strengthen employment protection in the form of law and also in the form a stronger role of trade unions to eliminate specific negative gender stereotypes and promote fair pay and work-life balance free of sex bias. Using a regression analysis, it is possible to determine how much of the total value of the gender pay gap can be explained by sub-factors such as length of work experience, age or education etc. Unexplained value will than represent a value of direct discrimination. It would be also interesting to research what average wage cuts a Czech woman will have for each of her new-born child as a result of her career break and the related maternity penalization. 


\section{CONCLUSION}

There is still a significant gap nationally between the earnings of men and women. According to government information, the gender pay gap has consistently been around $21 \%$ since 2002 .

In the analysed company the gender pay gap calculated on the random sample is $12 \%$. The hypothesis test determined that the difference between the company and national gender pay gap can be considered as significant in terms of improving the gender pay gap. Analysis shows that earnings increase with higher percentage of men in a given job and decrease with an increasing proportion of women. Looking at the performance of individual employees' gender pay inequality rates vary without directly correlating with productivity as well as human capital-related characteristics. Focusing on women, the so-called motherhood penalty still works, women with children achieve lower incomes than childless women and women (with or without children) achieve less than men in the analyzed company. In the random sample men on the same job earn more than women (abs. $4.012 \mathrm{CZK}$, rel. $12 \%$ ). The comparison of mothers and childless women shows that mothers earn less compared to childless women (abs. $-880 \mathrm{CZK}$, rel. $-3 \%$ ). In contrast, fathers earn more than childless men (abs. 2.834 CZK, rel. $9 \%$ ). In the random sample men with higher salaries were fathers. It can be argued, therefore, that male salaries were increased for their role as breadwinners, while the employer froze women's salaries during their career breaks due to their maternity leave and mothers are then penalized for their maternity. Even though mothers can reduce their income tax by claiming a tax relief to a dependent child, as well as men, but it can be claimed by only one of parents, they still do not equal the salary of childless women working in the same position. Even in the analyzed company, trade unions focus on wage increases, but they do not pay attention to gender inequalities and wage discrimination against women. Woman 's efforts to negotiate individual pay and rewards could be an example of what is not expected of women based on gender stereotypes. A woman can more often face negative reactions if she goes beyond what is understood as usual, normal and legitimate for women in a given society and culture, because according to gender stereotypes a such behavior is not expected of her. On the contrary, the negotiations on pay and rewards is expected to man as a breadwinner and is therefore generally understood as an acceptable behavior.

\section{ACKNOWLEDGMENT}

This research was supported by the VSB-Technical University of Ostrava, Faculty of Economics [grant number: SP 2019/7].

\section{REFERENCES}

Armstrong, M. \& Stephens, T. (2005). A Handbook of Employee Reward Management and Practice. London, United Kingdom: Kogan Page Limited.

Hindls, R., Hronova, S., Seger, J., \& Fisher, J. (2006). Statistika pro ekonomy. Praha, Czech Republic: Professional Publishing.

Krizkova, A., Pospisilova, K., Marikova, H., \& Markova Volejnickova, R. (2018). Rozdíly v odměňování žen a mužù v ČR. Praha, Czech Republic: Ministerstvo prace a socialnich veci.

Hodges, M. J., Budig, M. J. (2010). Who Gets the Daddy Bonus? Organizational Hegemonic Masculinity and the Impact of Fatherhood on Earnings. Gender \& Society, 24(6), 717-745.

Song, P., H., Lee, S., Y., D., Toth, M., Sing, S., R., Young, G. (2019). Gender Differences in Hospital CEO Compensation: A National Investigation of Not-for-Profit Hospitals. Medical Care Research and Review, 76(6), 830-846. 
Hultin, M., Szulkin, R. (1999). Wages and Unequal Access to Organizational Power: An Empirical Test of Gender Discrimination. Administrative Science Quarterly, 44(3), 453-472.

Yamamoto, Y., Matsumoto, K., Kawata, K., Kaneko, S., (2019). Gender-based Differences in Employment Opportunities and Wage Distribution in Nepal. Journal of Asian Economics, 64

Rafferty, A., (2019). Skill Underutilization and Under-Skilling in Europe: The Role of Workplace Discrimination. Work Employment and Society.

Kronberg, A., K., (2019). Workplace Gender Pay Gaps: Does Gender Matter Less the Longer Employees Stay? Work and Occupations.

Larraz, B., Pavia, CH., M., Vila, L., E., (2019). Beyond the gender pay gap. Convergencia-Revista de Ciencias Sociales, 81, 1-34.

Sato, K., Hashimoto, Y., Owan, H., (2019). Gender differences in Career. Journal of the Japanese and International Economics, 53.

Bargain, O., Doorley, K., Van Kerm, P., (2019). Minimum Wages and the Gender GAP in Pay: New Evidence from the United Kingdom and Ireland. Review of Income and Wealth, 65(3), 514-539.

Maume, D., J., Heymann, O., Ruppanner, L., (2019). National Board Quotas and the Gender Pay Gap among European Managers. Work Employment and Society.

Cook, A., Ingersoll, A., R., Glass, C., (2019). Gender gaps at the top: Does board composition affect executive compensation? Human Relations, 72(8), 1292-1314. 